\title{
THE EFFECT OF VARIOUS FACTORS ON TRAITS OF PERFORMANCE TESTED GILTS
}

\author{
M. Gogić ${ }^{1}$, M. Petrović ${ }^{2}$, B. Živković ${ }^{1}$, Č. Radović ${ }^{1}$, D. Radojković ${ }^{2}$ N. \\ Parunović $^{3}$, G. Marinkov ${ }^{1}$
}

\author{
${ }^{1}$ Institute for Animal Husbandry, Autoput 16, 11080, Belgrade-Zemun, Republic of Serbia \\ ${ }^{2}$ Faculty of Agriculture, University of Belgrade, Nemanjina 6, 11080, Belgrade-Zemun, Republic of \\ Serbia \\ ${ }^{3}$ Institute of Meat Hygiene and Technology, Kacanskog 13, 11000 Belgrade, Republic of Serbia \\ Corresponding author: gogic.marija@gmail.com \\ Original scientific paper
}

\begin{abstract}
Objective of this research wasto determine the effect of sire breed, genotype of the animal, farm and year on traits of performance tested gilts: age at the end of test (AET), life daily gain (LDG), fat thickenss 1 and 2 (FTL1 and FTL2) and depth of back muscle (MLD). Research included three farms during four consecutive years, and total of 4274 gilts were tested which derivied from 52 boar sires. Sires were pure breeds: Swedish landrace (SL, n=14), Large Yorkshire $(L Y, n=29)$, Pietrain $(P, n=6)$ and Durroc $(D, n=3)$, and their daughters belonged to following genotypes: Swedish landrace, large Yorkshire, Pietrain, Duroc, $F_{1}$ crosses LY $\times$ SL, SL $\times$ LY and $\mathrm{D} \times \mathrm{SL}$. It was established that sire breed, genotype of gilts and year had statistically significant $(\mathrm{P}<0,01$ and $\mathrm{P}<0,001)$ effect on all traits, only the effect of the farm on depth of MLD $(\mathrm{P}>0,05)$ wasn't registered. Sires within the breed had no effect on depth of MLD $(\mathrm{P}>0,05)$, where in case of sires within the Pietrain breed no effect on traits AET, FTL1 and FTL2 were observed and in case of sires within Duroc breed on AET, and for other traits the effect $(\mathrm{P}<0,05$ and $\mathrm{P}<0,001)$ of sires within the breed was determined. All traits of gilts depended statistically highly significantly $(\mathrm{P}<0,001)$ on body mass at the end of the test, except depth of back muscle.
\end{abstract}

Key words: boars, sires, genotype, gilts, performance test

\section{Introduction}

Programs of improvement of production characteristics which are applied today in pig production mainly consist of selection of best breeds, recommendations for adequate combinations of breeds in crossing and continuous improvement of production characteristics of pure breeds by using breeding animals of superior breeding value (Mijatović et al., 2005). Performance test is main method used ine valuation of breeding progeny - candidates for further selection. Today, in countries with developed livestock production modern 
mathematical-statistical methods are used which combine information on descendants, relatives, own production and offspring in order to evaluate as accuratley as possible the breeding value of pigs (Petrović, 2000). Performance test represents important selection measure in pig production. Objective of selection on farms is improvement of performances of the hers by increasing the frequency of desirable genes. Selection based on results of performance tests leads to improvement of economically important traits (life gain, back fat thickness, depth of back muscle), by 2-3\% per year (Schinkel, A.P., Bennett G., 1999, citirali Popov et al., 2006). In the research by Petrović et al. (1991), it was established that production traits of performance tested gilts vary under the influence of sires, year and season, whereas Petrovic et al. (1999) have established that sire, genotype of gilts and year statistically significantly influence the expression of all tested traits. Jukna et al. (2009) have stated that it is important to establish what are the best combinations of parents for breeding, since this can ensure significantly higher production and quality of pork in the country. Intensified selection for meat content has induced significant decrease of subcutaneous fat, even maybe of the content of intra-muscular fat (Bahelka et al., 2007). Content of intra-muscular fat is very important in regard to expression of typical properties of pig meat, such as succulence, taste, tenderness, etc.

\section{Material and methods}

Production traits of gilts in performance test were studied in three pig herds in four consecutive years. Research included 4274 gilts, 7 genotypes. The gilts included in the study derivied from 52 boars. Study included only sires with 10 and more daughters. At the end of test period, body mass of pigs was measured (MKT), ultrasound measuring of fat thickness (FTL1 and FTL2) and depth of MLD using Krautkrämer apparatus. In the first herd, there were 653 gilts, in the second 3296 and in the third 325 tested gilts. Within the sires of large Yorkshire breed (LY) there were 2609 gilts, of Swedish landrace (SL) 1415, of Pietrain (P) 117 and of (D) 133 gilts. In the first year, 360 gilts were tested, in the second - 912, in the third - 1431 and in the fourht - 1571 gilts. Test included following gentypes of gilts: Swedish landrace $(n=1041)$, Large Yorkshire $(n=979)$, Pietrain $(n=117)$, Duroc $(n=36), F_{1}$ crosses LY $\times$ SL $(n=1504), \operatorname{SL} \times$ LY $(n=499)$ and $\mathrm{D} \times \operatorname{SL}(n=98)$. Study included following traits: pre-slaughter age (AET), life daily gain, from birth to the end of the test (LDG), fat thickness between 3. and 4. lumbar vertebrae $7 \mathrm{~cm}$ laterally (FTL1), fat thickenss between 3. and 4. rib, from the rear, $7 \mathrm{~cm}$ laterally of the back line (FTL2) and depth of back muscle (MLD). Data was processed using the adequate computer program, i.e. method of Last squares (LSMLMW and MIXMDL-Harvey, 1990). The following were included into models: sire breed (R), sires within the breed $(\mathrm{O})$, animal genotype $(\mathrm{G})$, farm $(\mathrm{F})$ and year of testing $(\mathrm{S})$.

Two models were used for analysis of the age at the end of test, life daily gain, fat thickness 1 and 2 and depth of back muscle: 


$$
\begin{aligned}
& Y_{i j k l m}=\mu+F_{i}+R_{j}+O_{k: j}+S_{l}+b_{1}\left(X_{1}-\bar{x}_{l}\right)+\varepsilon_{i j k l m} \\
& Y_{i j k l}=\mu+F_{i}+G_{j}+S_{k}+b_{l}\left(X_{l}-\bar{x}_{l}\right)+\varepsilon_{i j k l}
\end{aligned}
$$

\section{Results and discussion}

All tested traits were corrected for same final body mass at the end of the test of 108,6 kg. Average values and standard deviations of corrected traits are presented in Table 1.

Table 1. Average values and variability of studied traits

\begin{tabular}{|l|l|r|r|}
\hline \multicolumn{2}{|c|}{ Trait $^{*}$} & \multicolumn{1}{c|}{$\bar{x} \pm$ SD } & \multicolumn{1}{c|}{$\mu \pm$ S.E. } \\
\hline AET & Age at the end of the test, days & $183,46 \pm 14,02$ & $190,95 \pm 0,55$ \\
\hline LDG & Life daily gain, g & $594,66 \pm 45,10$ & $568,99 \pm 1,70$ \\
\hline FTL1 & Fat thickness 1, mm & $10,04 \pm 2,48$ & $10,17 \pm 0,11$ \\
\hline FTL2 & Fat thickness 2, mm & $7,27 \pm 2,24$ & $7,48 \pm 0,09$ \\
\hline MLD & Depth of back muscle, mm & $57,54 \pm 4,68$ & $57,92 \pm 0,22$ \\
\hline
\end{tabular}

*Traits corrected for same final body mass of $108,6 \mathrm{~kg}$

In tables 2, 3, 4 and 5, LSM \pm SE values of studied traits in daughters according to sires within the breed and value for the breed are presented.

\begin{tabular}{|c|c|c|c|c|c|c|}
\hline \multicolumn{2}{|c|}{$\begin{array}{c}\text { Sources of } \\
\text { variation }\end{array}$} & $\mathrm{AET}^{2)}$, days & LDG, $g$ & FTL1, mm & FTL2, mm & MLD, mm \\
\hline $\mathrm{RO}^{1)}$ & $\begin{array}{l}\text { Sire } \\
\text { no. }\end{array}$ & & & & & \\
\hline \multirow{15}{*}{ 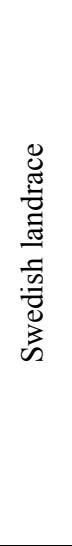 } & 1 & $187,50 \pm 0,97$ & $582,48 \pm 2,97$ & $10,12 \pm 0,20$ & $6,81 \pm 0,16$ & $57,23 \pm 0,39$ \\
\hline & 2 & $186,41 \pm 0,88$ & $584,85 \pm 2,69$ & $10,66 \pm 0,18$ & $7,26 \pm 0,15$ & $57,72 \pm 0,35$ \\
\hline & 3 & $187,64 \pm 1,16$ & $581,57 \pm 3,58$ & $10,04 \pm 0,24$ & $7,08 \pm 0,20$ & $57,77 \pm 0,47$ \\
\hline & 7 & $188,39 \pm 0,98$ & $575,04 \pm 3,00$ & $10,35 \pm 0,20$ & $7,38 \pm 0,17$ & $57,83 \pm 0,40$ \\
\hline & 15 & $185,64 \pm 2,62$ & $582,52 \pm 8,05$ & $10,43 \pm 0,53$ & $6,97 \pm 0,44$ & $57,56 \pm 1,06$ \\
\hline & 16 & $183,80 \pm 1,33$ & $588,14 \pm 4,08$ & $10,64 \pm 0,27$ & $7,84 \pm 0,23$ & $57,37 \pm 0,54$ \\
\hline & 17 & $187,41 \pm 0,94$ & $580,64 \pm 2,89$ & $9,93 \pm 0,19$ & $7,14 \pm 0,16$ & $58,04 \pm 0,38$ \\
\hline & 19 & $186,25 \pm 2,09$ & $583,30 \pm 6,43$ & $10,13 \pm 0,43$ & $7,00 \pm 0,35$ & $58,09 \pm 0,85$ \\
\hline & 21 & $185,98 \pm 2,04$ & $584,77 \pm 6,26$ & $11,00 \pm 0,41$ & $7,99 \pm 0,35$ & $58,53 \pm 0,83$ \\
\hline & 22 & $192,39 \pm 1,14$ & $570,47 \pm 3,49$ & $10,11 \pm 0,23$ & $7,37 \pm 0,19$ & $57,31 \pm 0,46$ \\
\hline & 27 & $189,17 \pm 2,93$ & $573,73 \pm 9,00$ & $9,95 \pm 0,60$ & $7,08 \pm 0,50$ & $57,56 \pm 1,19$ \\
\hline & 40 & $187,64 \pm 0,95$ & $585,82 \pm 2,90$ & $10,30 \pm 0,19$ & $7,38 \pm 0,16$ & $58,07 \pm 0,38$ \\
\hline & 43 & $185,48 \pm 1,34$ & $585,30 \pm 4,10$ & $10,16 \pm 0,27$ & $6,88 \pm 0,23$ & $57,65 \pm 0,54$ \\
\hline & 52 & $182,77 \pm 2,72$ & $590,71 \pm 8,35$ & $10,07 \pm 0,55$ & $8,71 \pm 0,46$ & $57,23 \pm 1,10$ \\
\hline & $\begin{array}{l}\text { Avera } \\
\text { ge }\end{array}$ & $186,89 \pm 0,55$ & $582,10 \pm 1,69$ & $10,28 \pm 0,11$ & $7,35 \pm 0,09$ & $57,71 \pm 0,22$ \\
\hline
\end{tabular}

Table 2. LSM \pm SE values of studied traits per each sire within the Swedish landrace breed

${ }^{1)}$ RO-sire breed; ${ }^{2}$ AET-age at the end of test; LDG-life daily gain; FTL1-fat thickness 1; FTL2-fat thickness 2; MLD-depth of back muscle 
In Table 2 we see that gilts of sire 52 had the highest LDG $(591 \mathrm{~g})$. Daughters of sires 17 and 27 had the thinnest FTL1 $(9,9 \mathrm{~mm})$, whereas the highest values for FTL1 and MLD were established in daughters of sire 21.

Table 3. LSM \pm SE values of studied traits per each sire within the Large Yorkshire breed

\begin{tabular}{|c|c|c|c|c|c|c|}
\hline \multicolumn{2}{|c|}{$\begin{array}{c}\text { Sources of } \\
\text { variation }\end{array}$} & $\mathrm{AET}^{2)}$, days & LDG, $\mathrm{g}$ & FTL1, mm & FTL2, mm & MLD, $\mathrm{mm}$ \\
\hline $\mathrm{RO}^{1)}$ & Sire no. & & & & & \\
\hline \multirow{11}{*}{ 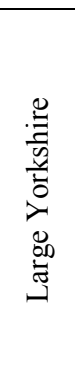 } & 8 & $190,96 \pm 1,78$ & $574,49 \pm 5,45$ & $10,35 \pm 0,36$ & $7,07 \pm 0,30$ & $57,03 \pm 0,72$ \\
\hline & 10 & $186,34 \pm 0,78$ & $581,98 \pm 2,41$ & $10,68 \pm 0,16$ & $7,49 \pm 0$ & $57,55 \pm 0,32$ \\
\hline & 13 & $198,69 \pm 3,23$ & $548,33 \pm 9,93$ & $10,95 \pm 0,66$ & $7,72 \pm 0$ & $58,20 \pm 1,31$ \\
\hline & 14 & $183,90 \pm 2,86$ & $589,59 \pm 8,77$ & $11,66 \pm 0,58$ & $8,44 \pm 0$, & $59,12 \pm 1,16$ \\
\hline & 26 & $192,03 \pm 2,63$ & $565,23 \pm 8,09$ & $9,57 \pm 0,53$ & $7,26 \pm 0$ & $56,45 \pm 1,07$ \\
\hline & 28 & $184,84 \pm 2,18$ & $590,19 \pm 6,68$ & $10,60 \pm 0,44$ & $7,75 \pm 0,37$ & $57,38 \pm 0,88$ \\
\hline & 34 & $184,85 \pm 1,78$ & $594,12 \pm 5,46$ & $11,79 \pm 0,36$ & $8,64 \pm 0,30$ & $56,14 \pm 0,72$ \\
\hline & 35 & $184,36 \pm 1,50$ & $598,73 \pm 4,59$ & $10,67 \pm 0,30$ & $8,28 \pm 0,25$ & $57,26 \pm 0,61$ \\
\hline & 50 & $186,82 \pm 2,40$ & $576,61 \pm 7,36$ & $10,95 \pm 0,49$ & $8,09 \pm 0,41$ & $57,92 \pm 0,97$ \\
\hline & 51 & $180,61 \pm 2,87$ & $601,91 \pm 8,80$ & $10,22 \pm 0,58$ & $8,26 \pm 0,49$ & $57,84 \pm 1,16$ \\
\hline & Average & $187,52 \pm 0,45$ & $581,56 \pm 1,38$ & $10,66 \pm 0,09$ & $7,75 \pm 0,08$ & $57,58 \pm 0,18$ \\
\hline
\end{tabular}

${ }^{1)}$ RO-sire breed; ${ }^{2)}$ AET-age at the end of test; LDG-life daily gain; FTL1-fat thickness 1; FTL2-fat thickness 2; MLD-depth of back muscle

Because of many sires of LY breed $(n=29)$, in Table 3, only sires with values of studied traits which are the lowest, the highest and around average are presented. Within sire breed LY, the oldest were animals offspring of sire number 13 (199 days) which have the lowest LDG (548 g), whereas the youngest were animals offspring of sire number 51 (younger by 18 days than daughters of sire number 13) with the highest values of LDG (602 g). The thinnest FTL2 was recorded in daughters of sire number 8 , and the thickest in daughters of sire 34 (difference 1,5 mm). The lowest depth of MLD was recorded in daughters of sire number 34, and the greatest in daughters of sire 14 (difference $3 \mathrm{~mm}$ ). When choosing the tested gilts as future candidates for selection, Kernerová et al. (2006) established that for genotype Czech VY (CLW) body mass at the end of the test was $127 \mathrm{~kg}$, at the age of 206 days and LDG of $609 \mathrm{~g}$, whereas for genotype CLWsire line the average mass of $124 \mathrm{~kg}$ was established, at the age of 202 days and LDG of $511 \mathrm{~g}$. In our research (Table 3.) values of LDG trait vary per sires from 548 to $602 \mathrm{~g}$, but animals finished the test earlier (191 days) with lower body mass $(108,6 \mathrm{~kg})$.

Variations in studied traits of daughters deriving from sires within the breed $\mathrm{P}$ are presented in Table 4 . The thinnest FTL1 was recorded in animals deriving from sire number 23 and FTL2 gilts from sire number 32. The thickest measured FTL 1 and FTL 2 werw recorded in daughters of sire 9. The lowest values of depth of back muscle were recorded in daughters of sire number 23 and the highest values in daughters of sire number 30, and difference between them was approx. $4 \mathrm{~mm}$. 
Table 4. LSM \pm SE values of studied traits per each sire within the Pietrain breed

\begin{tabular}{|c|c|c|c|c|c|c|}
\hline \multicolumn{2}{|c|}{$\begin{array}{l}\text { Sources of } \\
\text { variation }\end{array}$} & $\mathrm{AET}^{2)}$, days & LDG, $\mathrm{g}$ & FTL1, mm & FTL2, mm & MLD, mm \\
\hline $\mathrm{RO}^{1)}$ & Sire no. & & & & & \\
\hline \multirow{7}{*}{ 茎 } & 9 & $197,48 \pm 2,56$ & $544,05 \pm 7,85$ & $9,27 \pm 0,52$ & $6,31 \pm 0,43$ & $58,37 \pm 1,03$ \\
\hline & 23 & $206,60 \pm 3,00$ & $520,81 \pm 9,21$ & $6,95 \pm 0,61$ & $5,40 \pm 0,51$ & $57,88 \pm 1,21$ \\
\hline & 30 & $199,79 \pm 2,45$ & $541,30 \pm 7,52$ & $7,79 \pm 0,50$ & $5,63 \pm 0,41$ & $61,62 \pm 0,99$ \\
\hline & 32 & $200,75 \pm 2,78$ & $530,46 \pm 8,52$ & $7,55 \pm 0,56$ & $5,24 \pm 0,47$ & $58,67 \pm 1,12$ \\
\hline & 39 & $204,34 \pm 2,28$ & $523,27 \pm 7,01$ & $7,81 \pm 0,46$ & $5,81 \pm 0,39$ & $60,54 \pm 0,92$ \\
\hline & 42 & $207,56 \pm 3,23$ & $510,32 \pm 9,92$ & $8,11 \pm 0,66$ & $5,48 \pm 0,55$ & $59,79 \pm 1,31$ \\
\hline & Average & $202,75 \pm 1,17$ & $528,37 \pm 3,60$ & $7,91 \pm 0,24$ & $5,64 \pm 0,20$ & $59,48 \pm 0,48$ \\
\hline
\end{tabular}

${ }^{1)}$ RO-sire breed; ${ }^{2)}$ AET-age at the end of test; LDG-life daily gain; FTL1-fat thickness 1; FTL2-fat thickness 2; MLD-depth of back muscle

Table 5. LSM \pm SE values of studied traits per each sire within the Duroc breed

\begin{tabular}{|c|c|c|c|c|c|c|}
\hline \multicolumn{2}{|c|}{$\begin{array}{l}\text { Sources of } \\
\text { variation }\end{array}$} & $\mathrm{AET}^{2)}$, days & LDG, $\mathrm{g}$ & FTL1, mm & FTL2, $\mathrm{mm}$ & MLD, $\mathrm{mm}$ \\
\hline $\mathrm{RO}^{1)}$ & Sire no. & & & & & \\
\hline \multirow{4}{*}{ 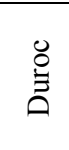 } & 31 & $184,77 \pm 1,38$ & $594,19 \pm 4,24$ & $12,01 \pm 0,28$ & $9,44 \pm 0,23$ & $57,27 \pm 0,56$ \\
\hline & 41 & $185,12 \pm 3,68$ & $582,33 \pm 11,29$ & $10,72 \pm 0,75$ & $7,79 \pm 0,62$ & $57,28 \pm 1,49$ \\
\hline & 48 & $189,97 \pm 1,85$ & $575,25 \pm 5,69$ & $12,71 \pm 0,38$ & $10,25 \pm 0,31$ & $56,17 \pm 0,75$ \\
\hline & Average & $186,62 \pm 1,47$ & $583,92 \pm 4,52$ & $11,81 \pm 0,30$ & $9,16 \pm 0,25$ & $56,91 \pm 0,60$ \\
\hline
\end{tabular}

${ }^{1)}$ RO-sire breed; ${ }^{2)}$ AET-age at the end of test; LDG-life daily gain; FTL1-fat thickness 1; FTL2-fat thickness 2; MLD-depth of back muscle

Sires number 31 and 41 were superior in relation to sire 48 since their daughters realized better results in performance test (Table 5).

The effect of farm and year on age at the end of test, life daily gain, fat thickness 1 and 2 and depth of back muscle in gilts is presented in Table 6 .

Table 6. The effect of farm and season (Model 1) on age at the end of test, life daily gain, fat thickness 1 and 2 and depth of back muscle (LSM \pm S.E.)

\begin{tabular}{|c|c|c|c|c|c|c|}
\hline \multicolumn{2}{|c|}{$\begin{array}{c}\text { Sources of } \\
\text { variation }\end{array}$} & \multirow{4}{*}{$\begin{array}{l}\mathrm{AET}^{2)} \text {, days } \\
187,47 \pm 0,72 \\
188,69 \pm 0,55 \\
196,69 \pm 0,95\end{array}$} & \multirow{4}{*}{$\begin{array}{c}\text { LDG, g } \\
579,10 \pm 2,23 \\
576,98 \pm 1,67 \\
550,88 \pm 2,91\end{array}$} & \multirow{4}{*}{$\begin{array}{c}\text { FTL1, mm } \\
10,89 \pm 0,15 \\
9,83 \pm 0,11 \\
9,79 \pm 0,19\end{array}$} & \multirow{4}{*}{$\begin{array}{r}\text { FTL2, mm } \\
7,56 \pm 0,12 \\
6,93 \pm 0,09 \\
7,93 \pm 0,16\end{array}$} & \multirow{4}{*}{$\begin{array}{l}\text { MLD, mm } \\
57,90 \pm 0,29 \\
57,61 \pm 0,22 \\
58,25 \pm 0,38\end{array}$} \\
\hline & 1 & & & & & \\
\hline E & 2 & & & & & \\
\hline & 3 & & & & & \\
\hline \multirow{4}{*}{ 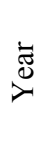 } & 1 & $195,22 \pm 0,95$ & $554,57 \pm 2,92$ & $10,75 \pm 0,19$ & $7,09 \pm 0,16$ & $57,92 \pm 0,39$ \\
\hline & 2 & $195,27 \pm 0,71$ & $556,75 \pm 2,18$ & $10,80 \pm 0,14$ & $7,43 \pm 0,12$ & $57,72 \pm 0,29$ \\
\hline & 3 & $187,97 \pm 0,60$ & $577,99 \pm 1,86$ & $9,43 \pm 0,12$ & $6,93 \pm 0,10$ & $57,66 \pm 0,24$ \\
\hline & 4 & $185,33 \pm 0,56$ & $586,64 \pm 1,71$ & $9,69 \pm 0,11$ & $8,45 \pm 0,09$ & $58,36 \pm 0,23$ \\
\hline \multicolumn{2}{|c|}{ MKT (b) } & $0,594^{2)^{* * *}}$ & $2,433^{* * *}$ & $-0,240^{* * *}$ & $-0,267^{* * *}$ & $0,012^{\mathrm{NS}}$ \\
\hline
\end{tabular}

${ }^{1)}$ AET-age at the end of test; LDG-life daily gain; FTL1-fat thickness 1; FTL2-fat thickness 2; MLDdepth of back muscle; ${ }^{2)} \mathrm{NS}=\mathrm{P}>0,05 ; *=\mathrm{P}<0,05 ; * *=\mathrm{P}<0,01 ; * * *=\mathrm{P}<0,001$ 
From Table 6, we can see that animlas from Farm 1 were the youngest (187 days), but with the highest LDG (579 g) and the thickest fat 2. Animals from Farm 3 were the oldest (197 days) with the lowest LDG $(551 \mathrm{~g})$, and the thinnest fat 1 but the greatest depth of MLD $(58,2 \mathrm{~mm})$. If we observe according to year, gilts decreased the age when they achieved body mass in the test of $108,6 \mathrm{~kg}$ and at the same time increased LDG with decrease in thickness of fat 1 and increase of depth of MLD. Regression effect of mass at the end of test had statistically very significant $(\mathrm{P}<0,001)$ effect on demonstration and expression of all studied traits, only on depth of MLD no statistically significant effect $(\mathrm{P}>0,05)$ was recorded. The effects of genotype, farm and year on traits of growth in gilts are presented in Table 7.

Table 7. The effects of genotype, farm and year (Model 2) on growth traits (LSM \pm S.E.)

\begin{tabular}{|c|c|c|c|c|c|c|}
\hline \multicolumn{2}{|c|}{$\begin{array}{c}\text { Sources of } \\
\text { variation }\end{array}$} & $\mathrm{AET}^{2)}$, days & LDG, $g$ & FTL1, mm & FTL2, mm & MLD, mm \\
\hline \multirow{7}{*}{$\begin{array}{l}\text { Genoty } \\
\text { pe }\end{array}$} & $1^{1)}$ & $188,33 \pm 0,46$ & $576,82 \pm 1,42$ & $10,20 \pm 0,09$ & $7,16 \pm 0,08$ & $57,62 \pm 0,18$ \\
\hline & 2 & $187,01 \pm 0,49$ & $583,08 \pm 1,52$ & $10,60 \pm 0,10$ & $7,63 \pm 0,08$ & $57,61 \pm 0,20$ \\
\hline & 3 & $202,74 \pm 1,14$ & $528,37 \pm 3,51$ & $7,86 \pm 0,23$ & $5,55 \pm 0,19$ & $59,60 \pm 0,45$ \\
\hline & 4 & $182,99 \pm 1,99$ & $593,01 \pm 6,12$ & $10,62 \pm 0,40$ & $7,93 \pm 0,33$ & $56,58 \pm 0,79$ \\
\hline & 5 & $186,16 \pm 0,42$ & $584,97 \pm 1,29$ & $10,43 \pm 0,08$ & $7,46 \pm 0,07$ & $57,64 \pm 0,17$ \\
\hline & 6 & $187,18 \pm 0,62$ & $585,13 \pm 1,90$ & $10,35 \pm 0,12$ & $7,22 \pm 0,10$ & $57,81 \pm 0,25$ \\
\hline & 7 & $188,36 \pm 1,31$ & $583,27 \pm 4,04$ & $12,82 \pm 0,26$ & $10,16 \pm 0,22$ & $56,94 \pm 0,52$ \\
\hline \multirow{3}{*}{ Farm } & 1 & $185,68 \pm 0,62$ & $585,31 \pm 1,91$ & $11,19 \pm 0,12$ & $7,77 \pm 0,10$ & $57,70 \pm 0,25$ \\
\hline & 2 & $186,40 \pm 0,43$ & $586,16 \pm 1,32$ & $10,17 \pm 0,09$ & $7,11 \pm 0,07$ & $57,37 \pm 0,17$ \\
\hline & 3 & $194,83 \pm 0,85$ & $557,66 \pm 2,61$ & $9,88 \pm 0,17$ & $7,88 \pm 0,14$ & $57,98 \pm 0,34$ \\
\hline \multirow{4}{*}{ 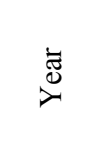 } & 1 & $194,10 \pm 0,78$ & $560,21 \pm 2,38$ & $11,01 \pm 0,16$ & $7,05 \pm 0,13$ & $57,50 \pm 0,31$ \\
\hline & 2 & $193,02 \pm 0,59$ & $564,41 \pm 1,80$ & $11,05 \pm 0,12$ & $7,52 \pm 0,10$ & $57,57 \pm 0,23$ \\
\hline & 3 & $185,87 \pm 0,51$ & $585,67 \pm 1,56$ & $9,66 \pm 0,10$ & $7,10 \pm 0,09$ & $57,46 \pm 0,20$ \\
\hline & 4 & $182,89 \pm 0,45$ & $595,23 \pm 1,39$ & $9,93 \pm 0,09$ & $8,68 \pm 0,08$ & $58,21 \pm 0,18$ \\
\hline \multicolumn{2}{|c|}{ MKT (b) } & $0,596^{3) * * *}$ & $2,463 * * *$ & $-0,025 * * *$ & $-0,028 * * *$ & $0,009^{\mathrm{NS}}$ \\
\hline
\end{tabular}

1) 1-SL, 2- LY, 3-P, 4-D, 5-LY $\times$ SL, 6-SL $\times$ LY, 7-D $\times S^{2}{ }^{2)}$ AET-age at the end of test; LDG-life daily gain; FTL1-fat thickness 1; FTL2-fat thickness 2; MLD-depth of back muscle; ${ }^{3)} \mathrm{NS}=\mathrm{P}>0,05$; $*=\mathrm{P}<0,05 ; * *=\mathrm{P}<0,01 ; * * *=\mathrm{P}<0,001$

When observing the genotype of gilts as source of variation it was established that animals of Pietrain breed were the oldest, and Duroc breed the youngest (variation of the trait AET was in the range from 183-203 days); the highest gain was recorded in animals of duroc breed and the lowest in Pietrain gilts (difference between them of even $65 \mathrm{~g}$ ); the lowest values of fat thickness 1 and 2 were observed in animals of Pietrain breed and the highest in animals $F_{1} \mathrm{D} \times \mathrm{SL}$ (difference between the lowest and the highest values of FTL1 and FTL2 was 
around $5 \mathrm{~mm}$ ); the greatest value of depth of back muscle was observed in Pietrain gilts, and the lowest in Duroc (difference between them 2,6 mm).

Levels of significance of effects included in the model on studied gilt traits are presented in Table 8.

Table 8. Statistical significance (level of significance) of effects included in the model (Model 1 and 2) on studied traits

\begin{tabular}{|c|c|c|c|c|c|c|}
\hline \multicolumn{2}{|c|}{ Sources of variation } & $\mathrm{AET}^{2)}$ & LDG & FTL1 & FTL2 & MLD \\
\hline \multirow{8}{*}{$\begin{array}{l}\bar{\Xi} \\
\overline{0} \\
\dot{\Sigma}\end{array}$} & $\mathrm{RO}^{1)}$ & $* * * 3)$ & $* * *$ & $* * *$ & $* * *$ & $* * *$ \\
\hline & $\mathrm{O}: \mathrm{SL}$ & $* * *$ & $*$ & $*$ & $* * *$ & NS \\
\hline & O:LY & $* * *$ & $* * *$ & $* *$ & $* * *$ & NS \\
\hline & $\mathrm{O}: \mathrm{P}$ & NS & $*$ & NS & NS & NS \\
\hline & O:D & NS & $*$ & $*$ & $* *$ & NS \\
\hline & Farm & $* * *$ & $* * *$ & $* * *$ & $* * *$ & NS \\
\hline & Year & $* * *$ & $* * *$ & $* * *$ & $* * *$ & $*$ \\
\hline & $\mathrm{R}^{2}$ & 0,335 & 0,395 & 0,127 & 0,254 & 0,022 \\
\hline \multirow{4}{*}{$\frac{\frac{N}{d}}{\frac{0}{2}}$} & Genotype & $* * *$ & $* * *$ & $* * *$ & $* * *$ & $* *$ \\
\hline & Farm & $* * *$ & $* * *$ & $* * *$ & $* * *$ & NS \\
\hline & Year & $* * *$ & $* * *$ & $* * *$ & $* * *$ & $* *$ \\
\hline & $\mathrm{R}^{2}$ & 0,309 & 0,369 & 0,114 & 0,239 & 0,013 \\
\hline
\end{tabular}

1) RO-sire breed; O:SL-sires within Swedish landrace breed; O:LY-sires within Large Yorkshire breed; O:P- sires within Pietrain breed; O:D- sires within Duroc breed; ${ }^{2)}$ AET-age at the end of test; LDG-life daily gain; FTL1-fat thickness 1; FTL2-fat thickness 2; MLD-depth of back muscle ${ }^{3)}$ $\mathrm{NS}=\mathrm{P}>0,05 ; *=\mathrm{P}<0,05 ; * *=\mathrm{P}<0,01 ; * * *=\mathrm{P}<0,001$

Čechova et al.(2002) have established that the genotype and environemnt factors influence the growth. This group of authors has studied the change in gain during four consecutive years and reached a conclusion that in both gilt genotypes (Czech large Yorkshire and Landrase) LDG has increased (33-48 g). In present study, increase of gain of gilts by more than $30 \mathrm{~g}$ was also established. In the period 1991-2000, Petrović et al. (2002) have determined the value of LDG of $458 \mathrm{~g}$ for tested gilts in production conditions on farms in Republic of Serbia. By comparison of said results to effects established for the period 2005-2008 (Petrović et al., 2009), the increase of the intensity of gain was established (517 to $458 \mathrm{~g})$, which coincides with results of our research that there was an increase in gain from fist to the fourth research year (difference between the first and the fourth research year was $35 \mathrm{~g}$ ). In concordance to present study, Radović et al. (2011) have stated 
that gilts of $\mathrm{P}$ breed had the thinnest fats 1 and 2, the greatest depth of back muscle compared to other genotypes. They have also established that genotype of gilts was statistically highly significant $(\mathrm{P}<0,01)$ source of variation of all analyzed traits of tested gilts, which is in concordance with present study. The effect of year on fat thickness and muscle depth of performance tested $F_{1}$ gilts of Polish Large Yorkshire and Polish Landrace (PLW $\times \mathrm{PL}$ i $\mathrm{PL} \times \mathrm{PLW})$ was studied by Nowachowicz et al. (2009). In this study, significant and highly significant effect of the year on fat thickness P2 was established (measured behind the last rib, $3 \mathrm{~cm}$ from the medial surface), which is in concordance with our research results $(\mathrm{P}<0,001)$. Szyndler-Nędza et al. (2010) have concluded that differences between genotypes of performance tested gilts (Polish LY, Polish Landrace, D and P) were sigificant $(\mathrm{P} \leq 0,05$ and $\mathrm{P} \leq 0,01)$ for all studied traits, which is in concordance with or results $(\mathrm{P}<0,01$ and $\mathrm{P}<0,001)$.

Obtained results that production traits of performance tested gilts vary under th influence of sires, genotype and years, are in concordance with results obtained by Petrović et al. (1991; 1999).

\section{Conclusion}

Based on obtained results, it was established that sire breed had statistically highly significant effect on all studied gilt traits $(P<0,001)$. Sires within different breeds have different effect on traits of their daughters $(\mathrm{P}<0,05, \mathrm{P}<0,01$ and $\mathrm{P}<0,001)$, and no effect on trait of MLD depth $(\mathrm{P}>0,05)$. Sires within the Pietrain breed had statistically significant effect $(\mathrm{P}<0,05)$ only on trait $L D G$, whereas on other traits their eefect was not significant, and sires within Duroc breed had statistically significant effect only on traits LDG, FTL1 and FTL2. In case of farm as source of variation of gilt traits, it can be concluded that farm had very significant effect on all studied traits $(\mathrm{P}<0,001)$, and no effect on MLD depth $(\mathrm{P}>0,05)$. Genotype of gilts as source of variation showed highly significant effect on all traits $(\mathrm{P}<0,01$ and $\mathrm{P}<0,001)$, as well as the year.

\section{Acknowledgements}

Research was financed by the Ministry of Education and Science, Republic of Serbia, project TR 31081 . 


\section{Uticaj različitih faktora na osobine performans testiranih nazimica}

M. Gogić, M. Petrović, B. Živković, Č. Radović, D. Radojković, N. Parunović, G. Marinkov

\section{Rezime}

Cilj ovog istraživanja je da se utvrdi uticaj rase oca, oca unutar rase, genotipa grla, farme i godine na osobine performans testiranih nazimica: uzrast na kraju testa (UKT), životni dnevni prirast (ŽDP), debljina slanine 1 i 2 (DSL1 i DSL2) i dubina leđnog mišića (MLD). Istraživanjem su obuhvaćene tri farme u četiri uzastopne godine, a ukupno je testirano 4274 nazimica koje vode poreklo od 52 oca-nerasta. Očevi pripadaju čistim rasama: švedski landras ( $\breve{S} L, n=14)$, veliki jorkšir $(V J, n=29)$, pijetren $(P, n=6)$ i durok $(D, n=3)$, dok njihove kćeri pripadaju sledećim genotipovima: švedski landras, veliki jorkšir, pijetren, durok, $F_{1}$ melezi $\mathrm{VJ} \times \mathrm{SL}, \breve{S} L \times \mathrm{VJ}$ i $\mathrm{D} \times \breve{S} \mathrm{~L}$. Utvrđeno je da rasa oca, genotip nazimica i godina utiču statistički značajno $(\mathrm{P}<0,01$ i $\mathrm{P}<0,001)$ na sve osobine, dok farma jedino nema uticaja na dubinu MLD ( $>0,05)$. Očevi unutar rase nisu uticali na dubinu MLD $(\mathrm{P}>0,05)$, pri čemu za očeve unutar rase pijetren nije utvrđen uticaj ni na osobine UKT, DSL1 i DSL2 kao i za očeve unutar rase durok na UKT, dok je za ostale osobine utvrđen uticaj $(\mathrm{P}<0,05$ i $\mathrm{P}<0,001)$ očeva unutar rase. Sve osobine nazimica su vrlo visoko statistički zavisile $(\mathrm{P}<0,001)$ od telesne mase na kraju testa osim dubine leđnog mišića.

\section{References}

BAHELKA I., TOMKA J., HANUSOVA E. (2007): The effects of probe type and intensity of ultrasound on accuracy of intramuscular fat prediction in Longissimus dorsi muscle of pigs. Biotechnology in Animal Husbandry, 23, 5-6, 87-95.

ČECHOVÁ M., TVRDOŇ Z. (2002): An influence of different growth ability of Czech Large White gilts and Landrace gilts on their reproductive performance. Czech Journal of Animal Science, 47, 8, 319-327.

HARVEY R.W. (1990): User's guide for LSMLMW and MIXMDL. Ver. PC-2, 1-91. JUKNA V., JUKNA Č., PEČIULAITIENE N., MEŠKINUTE-KAUŠILIENE E. (2009): The effect of boars and sows on meat quality and calorific values in the progeny. Biotechnology in Animal Husbandry, 25, 3-4, 161-172.

KERNEROVA N., VACLAVOVSKY J., MATOUŠEK V., HANYKOVA Z. (2006): The use of performance test parameters for selection of gilts before their placement into breeding. Czech Journal of Animal Science, 51, 6, 253-261. 
MIJATOVIĆ M., PETROVIĆ M., RADOJKOVIĆ D., JOKIĆ Ž. (2005): Uticaj očeva na fenotipsku varijabilnost proizvodnih osobina direktno testiranih nerastova. Biotechnology in Animal Husbandry 21, 3-4, 69-77.

NOWACHOWICZ J., MICHALSKA G., BUCEK T., WASILEWSKI P. D. (2009): Meat and fat content of crossbred gilts born and kept in Poland in Bydgoszcz breeding district in years 1995-2004. Journal Central European Agriculture, 10, 4, 367-374.

PETROVIĆ M., LATINOVIĆ D., STOJIĆ P., KOSOVAC O. (1991): Uticaj genetskih i faktora okoline na varijabilnost rezultata performans testa nazimica. Biotehnologija u stočarstvu, 7, 1-2, 25-32.

PETROVIĆ M., IGNJATOVIĆ I., STOJISAVLJEVIĆ N. (1999): Factors influencing varying of traits in peformance tested gilts. Biotechnology in Animal Husbandry, 15, 3-4, 21-30.

PETROVIĆ M. (2000): Stočarstvo, Poljoprivredni fakultet, Beograd-Zemun.

PETROVIĆ M., TEODOROVIĆ M., RADOJKOVIĆ D., RADOVIĆ I. (2002): Varijabilnost proizvodnih osobina svinja na farmama u Srbiji. Veterinarski glasnik, 56, 1-2, 89-96.

PETROVIĆ M., RADOJKOVIĆ D., MIJATOVIĆ M., RADOVIĆ Č. (2009): Mere selekcije u svinjarstvu. Sedmi simpozijum - Zdravstvena zaštita, selekcija i reprodukcija svinja-Srebrno jezero, 21-23. maj 2009. godine. Zbornik radova, 72-77.

POPOV R., I. RADOVIĆ, TRIVUNOVIĆ S., M. TEODOROVIĆ (2006): Analyse of performance test results for the gilts of different genotypes. Savremena poljoprivreda, 55, 1-2, 106-110.

RADOVIĆ Č., PETROVIĆ M., ŽIVKOVIĆ B., RADOJKOVIĆ D., MIJATOVIĆ M., GOGIĆ M., SAVIĆ R. (2011): Rezultati sprovođnja glavnog odgajivačkog programa u Centralnoj Srbiji. Deveti simpozijum - Zdravstvena zaštita, selekcija i reprodukcija svinja - Srebrno jezero, 26-28. maj 2011. godine. Zbornik radova, 18-25. SZYNDLER-NĘDZA M., TYRA M., RÓŻYCKI M. (2010): Coefficients of heritability for fattening and slaughter traits included in a modified performance testing method. Annals of Animal Science, 10, 2, 117-125. 